\title{
Pensamento Econômico no Brasil Contemporâneo
}





\title{
Pensamento econômico no Brasil contemporâneo
}

\author{
TAMÁS SZMRECSÁNYI
}

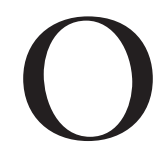

S ARTIGOS publicados neste número de ESTUDOS AVANÇADOS constituem uma seleção parcial e editada dos trabalhos que integram o dossiê Pensamento Econômico no Brasil Contemporâneo, cujas versões integrais e sem retoques estão sendo reunidas num caderno especial da Coleção Documentos do Instituto de Estudos Avançados, a ser lançado até o final do corrente ano. Ainda em 2001 deverá também ser divulgada uma segunda seleção, num dos próximos números da revista. Por ora, cabe apenas explicitar e justificar os critérios que nortearam nossos convites, bem como a organização do dossiê e da presente seleção.

Na sua valiosa História da Análise Econômica, Joseph Alois Schumpeter, um dos dois maiores economistas do século XX (o outro foi John Maynard Keynes), estabeleceu uma distinção significativa entre os conceitos de pensamento econômico em geral (economic thought), de economia política (political economy), e de ciência econômica propriamente dita - por ele denominada Análise Econômica (economic analysis) ou simplesmente Economia (Economics). O primeiro desses conceitos abrange, segundo Schumpeter, as diversas opiniões sobre temas e problemas econômicos numa dada época e sociedade. Por sua vez, a segunda noção envolve fundamentalmente as políticas econômicas (economic policies) formuladas, advogadas ou promovidas por determinados autores e/ou grupos de interesses. Mas, para ele, é apenas o terceiro conceito que interessa, por incluir os aspectos propriamente científicos tanto do Pensamento Econômico como da Economia Política. Aspectos dos quais as ideologias obviamente não estão ausentes, mas cujas proposições e conhecimentos objetivos são derivados da investigação sistemática, e alcançados através do emprego de um instrumental analítico que compreende estudos de natureza histórica, estatística e teórica.

Embora essa distinção nem sempre pareça ter sido devidamente aceita e entendida pelos diversos autores e editores, fizemos o possível para ater-nos a este terceiro âmbito mais específico e mais especializado do pensamento econômico, dando preferência ao confronto de idéias científicas face às meras comparações de políticas econômicas, ou às simples apresentações de determinados pontos de vista sobre a situação e o desenvolvimento da economia em que vivemos. Por outro lado, em termos cronológicos, procuramos não recuar além dos últimos 50 anos. 
Esta última opção se justifica, em parte, pelo fato da profissionalização dos economistas ter-se consolidado no Brasil apenas no referido período, a partir de sua regulamentação pela Lei . $^{\circ} 1.411$, de 13 de agosto de 1951 , poucos anos depois da criação e do funcionamento inicial de nossos primeiros cursos universitários de Ciências Econômicas. E em parte, pela publicação, também naquela época, de um primeiro balanço retrospectivo do desenvolvimento da disciplina no País. Trata-se do ensaio de Paul Hugon sobre 'A Economia Política no Brasil', capítulos XIII da obra coletiva As Ciências no Brasil (São Paulo, Melhoramentos, 1955), coordenada por Fernando de Azevedo. Considerando que tanto o autor do referido capítulo como o organizador da coletânea eram então professores da USP, pareceu-nos adequado que coubesse à mesma Universidade realizar o atual balanço e divulgar os seus resultados através de um ou mais números da revista de seu Instituto de Estudos Avançados.

Os trabalhos que figuram neste número foram agrupados em três blocos temáticos. O primeiro, compreendendo quatro artigos, refere-se às principais CORRENTES TEÓRICAS do atual pensamento econômico brasileiro, e representa o único conjunto publicado em sua totalidade. Já o segundo, relativo aos TEMAS EM DEBATE, aparece aqui com apenas dois artigos, devendo portanto ter seqüência num dos próximos números desta revista. $\mathrm{O}$ mesmo deverá ocorrer com o terceiro, que traz as análises de algumas FIGURAS REPRESENTATIVAS, todas já falecidas. Além disso, haverá um quarto, dedicados aos canais institucionais de formação e difusão do pensamento econômico no Brasil contemporâneo - tais como os centros de pesquisa e os encontros científicos na área de Economia.

Tamás Szmrecsányi, membro do Conselho Editorial de ESTUDOS AVANÇADOS e editorassociado desta edição, é professor do Departamento de Política Científica e Tecnológica (DPCT) do Instituto de Geociências da Universidade Estadual de Campinas (Unicamp). 